\title{
The contribution of public capital towards economic growth: A KwaZulu-Natal case study
}

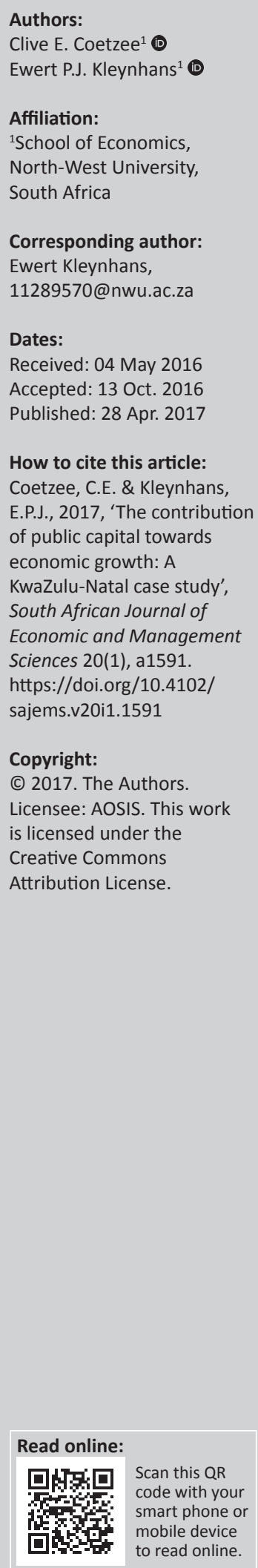

Background: The adequate supply of infrastructure is essential to ensure increasing productivity and economic growth. Research found this relationship to be significantly positive. The external effects that spending on public capital has on the production function of private firms stimulates economic growth overall. This implies that public capital inputs should be incorporated into the production function.

Aim: The way provincial or regional growth depends on infrastructure is investigated in this article and it is applied to data from KwaZulu-Natal province, as an illustration.

Setting: This study investigates the extent to which infrastructure in KwaZulu-Natal province in South Africa leads towards economic growth of the province.

Methods: From a theoretical framework, this article develops an endogenous growth model, which investigates the association between provincial public capital stock expenditure and economic growth. Data series for public capital formation are first developed to apply in this study and others to follow. Econometric techniques are then employed, using quarterly data between 2001 and 2015, to assess the set hypothesis that growth in expenditure on public capital leads to national economic growth.

Results: The empirical results support the argument of a positive relationship between provincial capital stock and economic growth in the long-term. The findings also suggests that the long-term causality or effect fades over time, albeit slowly.

Conclusion: The nature and statistical significance of the long-term equilibrium relationship seems to be ambiguous at best. Some evidence of an equilibrium relationship in the short-term was, however, also observed. In conclusion, there also seems to be some causality between provincial capital stock and provincial gross domestic product in the short-run.

\section{Introduction}

This article investigates the extent to which the economic growth of a region is stimulated through the expenditure on public capital by the authorities. The extent to which regional growth and economic performance were influenced by infrastructure had been researched quite extensively in the United States, and it is now being recognised that the decline in public expenditure on infrastructure in the United States was a major contributor to the extensive decline in national productivity growth in the 1970s and 1980s (Holtz-Eakin \& Schwartz 1994). This led to much research on the relationship between public capital, national productivity and growth.

The fact that higher investments lead to higher output in future is accepted intuitively by most (King \& Levine 1994). The concept of capital fundamentalism was built on this assumption, which can then be extended to assume that higher levels of national capital stocks lead to higher national economic growth as it raises national production.

Research, especially in poorer counties, provided much evidence in this regard. Correspondingly, capital fundamentalists emphasise the importance of increasing a county's capital stock in order to generate faster economic growth and development. Capital fundamentalism saw this as a solution to many countries' growth problems. To enhance economic development in a country, the most important aspect of policy design should therefore be focused on obtaining a higher stock of physical capital.

This article aims to develop a new data time series of provincial public capital stock for the KwaZulu-Natal Province of South Africa, and then apply it to investigate the extent to which physical capital stock can promote economic growth in this province. The data series on capital 
stock will be constructed using the perpetual inventory method (PIM) and adjusted for depreciation, which is a unique contribution of this study.

In the next section, attention will be given to a literature study on previous research related to the role of infrastructure and public capital in the promotion of economic prosperity, followed by an exposition of the theoretical principles on which this article is based.

\section{Previous research on the topic}

In previous research, a positive relationship was established between infrastructure and economic growth. In a 1994 report, the World Bank stated that a 1\% rise in infrastructure increase across all countries' gross domestic product by $1 \%$. Researchers in South Africa also found similar relationships (see, e.g., Bogetic \& Fedderke 2006; Fedderke \& Garlick 2008; Fedderke, Perkins \& Luiz, 2006; Volkwyn \& Kleynhans 2014; Visser et al. 2015).

Nannan and Jianing (2012) initiated the debate stressing the importance of infrastructure for private entrepreneurship, living quality, prosperity and the environment. Aschauer (1989) also focused on the way infrastructure leads to economic development. He also refers to other researchers that found similar relations between capital stock and production income, which occur not only in single economies but also across countries. A relationship between growing private returns on capital and more public capital is also noted but theory and practice also indicate that higher public expenditure can crowd out private sector investments (Munnell 1990). Using production functions for the timespan between 1965 and 1983, Aschauer found that public productivity rises significantly with core infrastructure. It was, however, found that the marginal product of public capital was much higher than that of private capital.

Much research was conducted on the relation between public capital and productivity (Gupta et al. 2011). Several estimated production functions add public capital stock as another factor of production. Others estimated profit and cost functions, which included public capital, and some followed a vector auto regression (VAR) approach, which enables researchers to have very little restrictions.

Literature in this regard generally reports on macro-economic production functions that includes public capital. Capital stock is either included as a factor of production or affects those factors through its effect on multifactor productivity. Most researches have, however, included both these effects and had problems to distinguish between these direct and indirect effects (De Haan, Romp \& Sturm 2007).

Zainah (2009) stated that government expenditure on capital enhances capital accumulation in the private sector, leading to economic prosperity. Public expenditure saves the private sector costs on infrastructure, and this leads to higher returns on private capital and higher productivity.
There exists complementarity between public and private investments. The productivity of the factors of production increases everywhere and adjustments lead to cost savings.

Most economists and politicians agree that expenditure on public infrastructure is essential when designing competition policy for a region. Decreasing cost structures that lead to better capital stock attracts investments, private capital and resources, leading to higher output and income in the region (Egger \& Falkinger 2003; Haughwout 2002).

Public capital is often regarded as an input factor of production of private firms. In this way, it has an external effect that lowers production costs and improves production and income of private enterprises (Fedderke \& Garlick 2008:12; Kalaitzidakis \& Tzouvelekas 2007). This was investigated by Barro (1990) who incorporated total public expenditure into his production functions or Turnovsky (1997) who modelled it as part of the total public stock.

Canning and Pedroni (2004) estimated a large panel data study, considering the information of many countries between 1950 and 1992, to ascertain their relationship between public capital and economic growth in the longterm. The study also examined the role of innovations. Instead of investment figures, they considered physical aspects such as the size of a country's power plants, and the number of telephones and the kilometre of roads in the region of study.

Several researchers, including Canning and Pedroni (2004), Lee, Pesaran and Smith (1997) and Cheung and Lai (2000), found unit roots existed in the data on public capital, as well as the per capita gross domestic output. The co-integration that were found between this data enabled the researchers to design a model that could distinguish between the short- and long-term effects; and also extended the research to crosscountry averages. The study found bi-directional causality in the short and long-term. They found that shocks in infrastructure have a very strong impact on national income and that infrastructure also has a long-term effect on income. The study also found that the public capital stock of many countries was in excess of the optimal required amount. This over-supply was also found by the research of Ghali (1998) and Devarajan, Swaroop and Zou (1996).

In order to achieve regional development and growth, public investment in infrastructure is essential (Márquez, Ramajo \& Hewings 2010). As the long-term effect was already indicated above, permanent increases of infrastructure should exist to support private sector development. 'New Growth Theory' (NGT) and 'New Economic Geography' (NEG) models emphasise the importance of capital expenditure by the authorities in order to ensure economic development.

Applying the research findings of others in metaregression analysis, it was found that the output elasticity of infrastructure is significantly positive (Bom \& Litghart 2010). The output elasticity of public capital was on average 
estimated to be 0.5 , and their benchmark for conditional elasticity was 0.17 . This elasticity ranged between $28.8 \%$ and $32.6 \%$ in 2001 for the United States. Much variation in primary estimates was found and across countries much heterogeneity was also found.

Onakoya and Somoye (2013) investigated the disaggregated effect of infrastructure on the income of the various sectors of Nigeria. They used a three-stage least squares (3-SLS) regression and simultaneous equations to model the country's economy. As the case in other research, they also established a positive relation between the expenditure on public infrastructure and economic growth. They did, however, also find indications of 'Dutch disease', as spending on infrastructure led to higher oil production, while the agriculture and manufacturing sectors are neglected and their growth rates declined. Their results did suggest that higher public expenditure on capital leads to an increase in private investments, but that the effect on the service sectors is insignificant.

Research that studied the relationship between public capital investment and economic progress in China by Nannan and Jianing (2012) also indicated a positive relationship, justifying their large expenditure aimed to minimise the impact of the global financial crisis. China's strategy to invest in public infrastructure to enhance economic growth can in this situation be regarded as a success. They studied Chinese data over the period 1988-2007 and estimated output elasticities using Cobb-Douglas production functions, which they developed into a gross productive equation.

Sava and Zugravu (2010) studied the correlation coefficients between infrastructure and national income for Romania using regression analysis over the period 2006-2009, and found a similar positive relationship, although not very strong. Higher government expenditure on capital thus also led to economic development in Romania.

A study on Mauritius found that expenditure on public capital led to significant increases in economic growth. Zainah (2009) also found indirect effects on private investments and the accumulation of private capital. The study estimated production functions based on Solow's growth model and also applied a vector error correction model (VECM), which is able to consider feedback effects.

On the contrary, not all studies agree. Several studies found that infrastructure expenditure by the authorities may also have a negative impact on the private sector and long-term national economic growth.

Gregoriou and Ghosh (2009) studied 15 industrialised nations and obtained mixed results. They found the relationship to be negative for Thailand and Brazil in the long-term, but current spending to be positive. On the contrary, Zimbabwe and Sudan enjoyed no benefit from any of these kinds of public expenditure. A study on Belgium indicated a negative relationship between the rate of employment and expenditure on public capital (Everaert \& Heylin 2004). An increase of 1\% in this kind of public expenditure led to an increase in private sector unemployment of $0.32 \%$ (Sava \& Zugravu 2010). In these cases, a relationship between public expenditure on capital and economic growth was found, but it was negative probably because of a crowding-out effect of private investments. The following section explains the basic theoretical basis of the current research.

\section{Theoretical principles}

This study is based on production functions to determine to what extent expenditure on public capital by the provincial authorities leads towards the economic growth of the province. Public capital is regarded as an input factor of production into the provincial production function. This expenditure does, however, reduce other kinds of investments (Barro 1990). The production function is specified as:

$Y_{t}=A f\left(S_{t}, K_{t}, G_{t}\right)=A_{t} S_{t}^{\alpha} K_{t}^{\beta} G_{t}^{\gamma}$

[Eqn 1]

where $Y_{t}$ is the total real provincial production and income (gross domestic product), $t$ is the time period, $K_{t}$ is the aggregate total national capital stock (general government and private) in the province (excluding aggregate provincial public capital stock), $G_{t}$ is the aggregate provincial public capital stock, while $S_{t}$ represents the skill adjusted aggregate provincial labour supply.

Rather than using raw labour (Gupta et al. 2011), this study constructs and uses skill adjusted labour incorporating data on the average literacy rate. The level of technology is represented by ' $\mathrm{A}$ ', as in other Cobb-Douglas production functions, and $\alpha, \beta$ and $\gamma$ are normal distributed parameters.

The empirical analysis adopted by this approach specifies the aggregate input-output production relationship as:

$Y_{t}=A_{0} S_{t}^{\alpha} K_{t}^{\beta} G_{t}^{\gamma} e^{\lambda_{t}+\varepsilon_{t}}$

[Eqn 2]

where $\mathrm{A}_{0}$ indicates the level of technology at the start of the research period (2001). The assumption is that year-specific intercepts $\lambda_{t}$ may represent external technology shocks. Taking logarithms yields:

$\ln Y_{t}=a_{0}+\lambda_{t}+\alpha \ln S_{t}+\beta \ln K_{t}+\gamma \ln G_{t}+\varepsilon_{t}$

[Eqn 3]

The estimation of such a relationship and determination to what extent the stock of provincial capital stock affects growth of the provincial economy requires the researchers to construct a dataset of provincial capital goods, which first takes depreciation into account. This is one of the major contributions of this study. The following section studies the growth in KwaZulu-Natal, followed by the design of the database for public capital.

\section{Provincial growth performance}

In 2015, KwaZulu-Natal's gross domestic product was estimated to be approximately R480 billion (2010 prices). 
Provincial output increased from R79 billion during the third quarter of 2001 to R121 billion during the third quarter of 2015 (2010 prices). Economic activity picked up robustly from 2000 to 2008 (with $4.42 \%$ average annual growth), and thereafter grew moderately and ultimately decreased $(-1.78 \%)$ in 2009 because of the global financial crisis. Positive growth resumed during 2010, albeit at a very modest pace with the provincial economy recording 3.43\%, 3.54\% and 2.55\% of growth during 2010, 2011 and 2012, respectively (Figure 1). Between 2010 (first quarter) and 2015 (third quarter), the provincial growth has steadily declined, mostly because of domestic risk factors, including growing labour unrest, electricity shortages and political uncertainties, as well as the downturn in the commodities and Chinese economic cycles (2.10\% during 2013 and 1.82\% in 2014).

For non-stationarity, the seasonal adjusted provincial gross domestic product per skill adjusted labour supply (Figure 2) in $\log$ form is tested. To perform the unit root test on an autoregressive model (AR)(p), the regression was determined as:

$y_{t}=\alpha+\delta_{t}+\beta y_{t-1}+\sum_{j=1}^{k} \theta_{j} \Delta y_{t-j}+u_{t}$

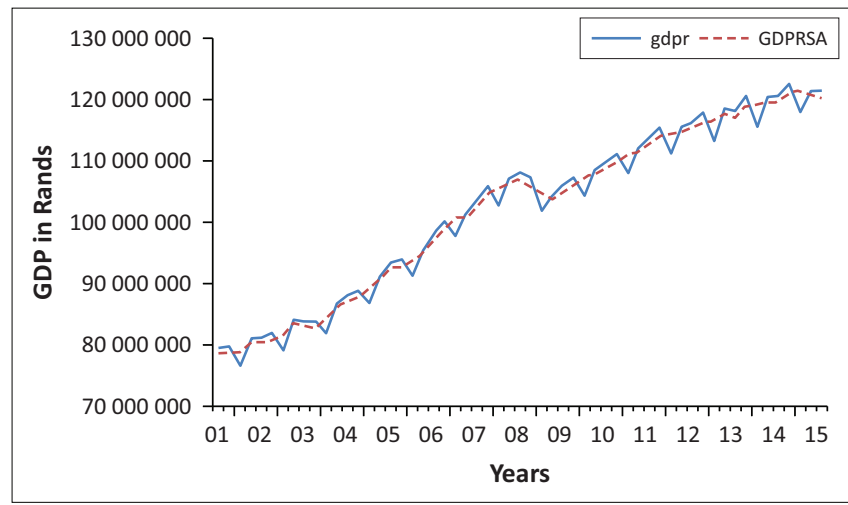

Source: Statistics South Africa, 2016, Gross domestic product, Statistical Release P0441, viewed 08 April 2017, from http://www.statssa.gov.za/publications/P0441/P04414thQuarter2016. pdf; Coetzee, C.E., 2017, KZN Database. KwaZulu-Natal Provincial Treasury, Pietermaritzburg South Africa

FIGURE 1: Provincial and seasonal adjusted gross domestic product ( $\mathrm{R}$ billion, constant 2010 prices).

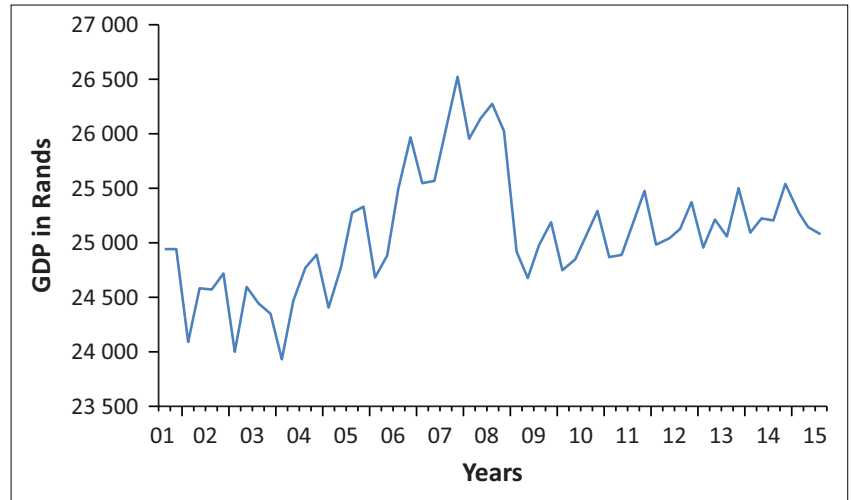

Source: Statistics South Africa, 2016, Gross domestic product, Statistical Release P0441, viewed 8 April 2017, from http://www.statssa.gov.za/publications/P0441/P04414thQuarter2016.pdf Coetzee, C.E., 2017, KZN Database. KwaZulu-Natal Provincial Treasury, Pietermaritzburg South Africa

FIGURE 2: Provincial seasonal adjusted gross domestic product per skill adjusted labour supply (R billion, 2010 prices).
The test statistics suggest that the variable is stationary in the first difference form and is integrated to the order of 1 or I(1). The stationary variable (first difference of the log of the provincial seasonal adjusted gross domestic product per skill adjusted labour supply in 2010 prices) is displayed in Figure 3.

The following section describes the way the provincial capital base was constructed and estimated.

\section{Constructing a net fixed provincial government capital stock series for the province}

In economic theory, capital goods, such as computers, buildings, vehicles and machines, are always regarded as an important production factor (Berlemann \& Wesselhöft 2012). Data on such capital stock is required to determine its impact on total output and income. Data on the development of the capital stock have, however, been unavailable for most countries for a considerable time and this also applies to the province of KwaZulu-Natal.

The development of datasets on large provincial capital stock is mostly unavailable and this necessitated the development of a dataset, especially for this research. Statistical offices that did develop such datasets in the past all used the PIM. Examples include Griliches (1980), Nehru and Dhareswhar (1993), Fuente and Domenech (2000), Kamps (2006) and Derbyshire, Gardiner and Waights (2010).

Investment in capital goods implies an increase in capital goods. The principle PIM method, therefore, also regards public expenditure on infrastructure as an inventory item and capital formation as investments. After an investment, the owner enjoys utility from that capital good acquired and the quality thereof declines as time expires. In principle, capital goods will always have some use, indicating some perpetual value, but with time the capital goods will deteriorate and its value will also depreciate. The value of

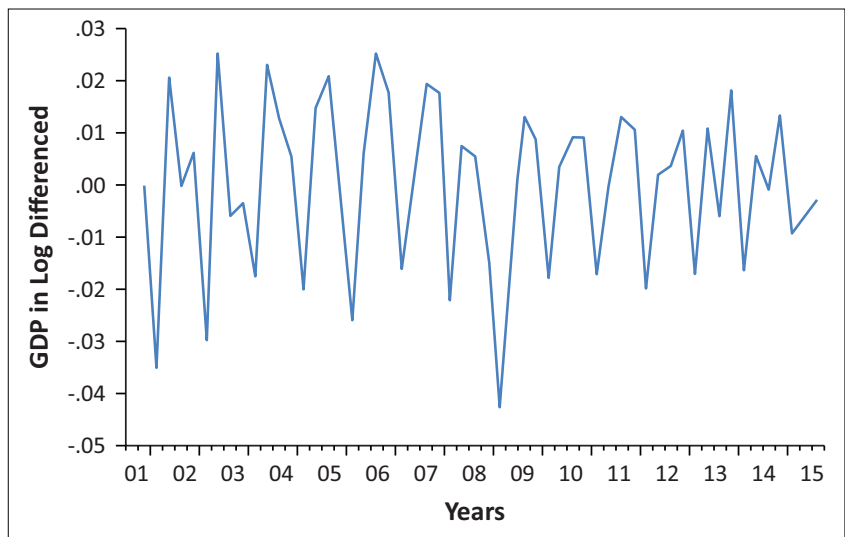

Source: Statistics South Africa, 2016, Gross domestic product, Statistical Release P0441, viewed 08 April 2017, from http://www.statssa.gov.za/publications/P0441/P04414thQuarter2016. pdf; Coetzee, C.E., 2017, KZN Database. KwaZulu-Natal Provincial Treasury, Pietermaritzburg, South Africa

FIGURE 3: Log of first difference of the provincial seasonal adjusted gross domestic product per skill adjusted labour supply (2010 prices). 
public capital goods after depreciation can then be estimated as:

$K_{t}=K_{t-1}-\delta K_{t-1}+G F K_{t}=(1-\delta) K_{t-1}+G F K_{t}$

where $K_{t}$ is the capital stock during time $t, G F K_{t}$ is gross fixed capital formation (GFCF) and $\delta$ is the rate of depreciation (assumed constant over time). The way that researchers estimated the initial levels of capital stock differs between researchers. The approaches most frequently used in the literature are the steady state, disequilibrium and synthetic time series methods.

This article does not employ any of the above approaches but rather a national disaggregation approach (predicting times series by related series) to estimate initial provincial government capital stock. Such an approach allows for the transition from aggregate indicators to disaggregate indicators. More specifically, an attempt was made to estimate the value of public capital of KwaZulu-Natal provincial, with analogous indicators that are available at the national and provincial level. Vidoli and Mazziotta (2010) stated that Chow-Lin's approach allows for the reconstruction in an appreciably precise way of the infrastructural index at the disaggregate level on the basis of the corresponding indicator at the superior territorial level. Polasek (2009) demonstrated how regional data can be developed from national data. Chow and Lin (1971) disaggregated national data for their regional spatial analysis, when only the total country-wide figures were available. The national disaggregation approach estimates are derived from three basic components:

- an indicator that measures the desired characteristics reliably at the national level

- auxiliary information that provides provincially detailed data

- models to relate the indicator estimates to the auxiliary information.

Since reliable provincial government gross capital formation is only available from 2001, the total provincial government capital stock from 2001 has to be estimated. This is done using the total national government gross capital stock data (national indicator), published by the South African Reserve Bank (SARB), which was then disaggregated on a provincial level (equitable share data). Calculation of the total provincial government capital stock is based on the following steps:

- Step 1: The total fixed capital stock (general government) based on the SARB statistics was R1.4 trillion during 2001 (constant 2010 prices).

- Step 2: National government distributes on average approximately $32 \%$ of its resources to the nine provinces through the equitable share system and therefore it is estimated that the total fixed capital stock (provincial government) was R450 billion in 2001 (constant 2010 prices).

- Step 3: Of this 32\%, KwaZulu-Natal receives approximately $21 \%$ and therefore the estimated total fixed capital stock (KwaZulu-Natal) was R94 billion in 2001(constant 2010 prices).

The rate of depreciation is assumed at $1 \%$ since the majority of total fixed provincial government capital stock consists of long service life capital.

The Organisation for Economic Cooperation and Development and Eurostat (2017) defines GFCF:

as the acquisition, less disposals, of fixed assets plus major improvements to, and transfer costs on, land and other nonproduced assets. The assets acquired may be new or they may be used assets that are traded on second-hand markets. The assets disposed of may be sold for continued use by another economic unit, they may be simply abandoned by the owner or they may be sold as scrap and be broken down into reusable components, recoverable materials, or waste products. (OECD 2009:126)

\section{The OECD (2001) states that GFCF:}

is measured by the total value of a producer's acquisitions, less disposals, of fixed assets during the accounting period plus certain additions to the value of non-produced assets realised by the productive activity of institutional units. (p. 1)

GFCF is a 'gross' value as the figures are neither adjusted in any way nor adapted for depreciation or consumption of fixed capital. It also excludes land sales and purchases. Figure 4 displays the provincial government GFCF in both nominal and real terms. In an effort to determine the real provincial government GFCF, the gross domestic product deflator was applied. Figure 5 displays the real provincial GFCF after seasonal and non-seasonal adjustments.

Figure 6 displays the real seasonal adjusted fixed provincial government capital stock applying the PIM where:

$K_{2001}=\mathrm{R} 94299811200, G F K_{2001}=\mathrm{R} 757426628$ and $\delta=1 \%$

The log of the seasonal adjusted fixed provincial government capital stock per skill adjusted labour supply ( $R^{\prime} 2010$ prices)

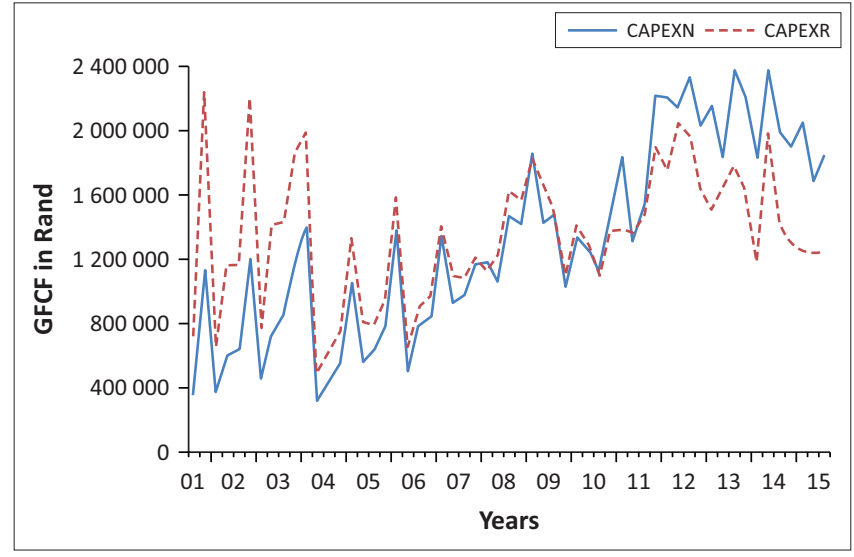

Source: Coetzee, C.E., 2017, KZN Database. KwaZulu-Natal Provincial Treasury, Pietermaritzburg, South Africa

FIGURE 4: Nominal and real provincial government total capital formation (R'000). 


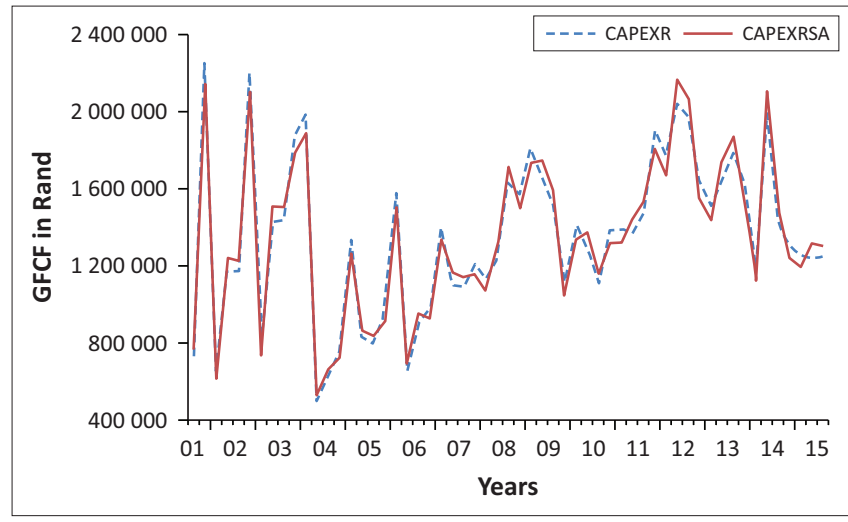

Source: Coetzee, C.E., 2017, KZN Database. KwaZulu-Natal Provincial Treasury, Pietermaritzburg, South Africa

FIGURE 5: Real provincial government and real seasonal adjusted provincial government total capital formation ( $\left.\mathrm{R}^{\prime} 000\right)$.

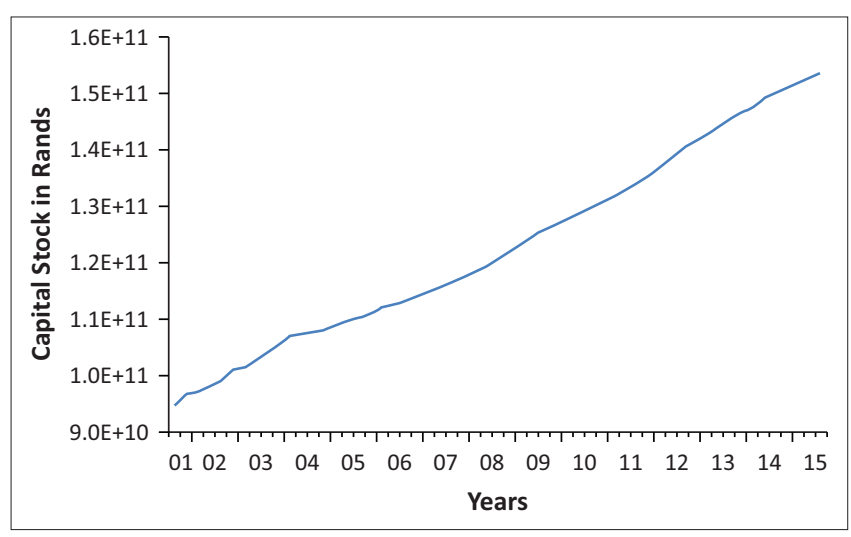

FIGURE 6: Seasonal adjusted fixed provincial government capital stock (2010 prices).

is tested for non-stationarity against the alternative that the variable is trend stationary (Figure 7). The test statistics suggest that first difference stationary exists and is therefore integrated to the order of 1 or I(1). The stationary variable (first difference of the $\log$ ) of the seasonal adjusted fixed provincial government capital stock per skill adjusted labour supply is displayed in Figure 8.

This constructed capital database was then applied to determine the contribution of public infrastructure towards provincial economic growth.

\section{Provincial fixed capital stock and provincial economic performance}

The behaviour of the provincial gross domestic product per skill adjusted labour supply and total fixed capital stock per skill adjusted labour supply over the period 2001 (third quarter) to 2015 (third quarter) are displayed in Figure 9. Some correlation between the two variables seems to be present.

A regression function for the variables displayed in Figure 9 can be estimated. It shows provincial gross domestic product per skill adjusted labour supply and total fixed capital stock per skill adjusted labour supply in first difference log format using the following equation:

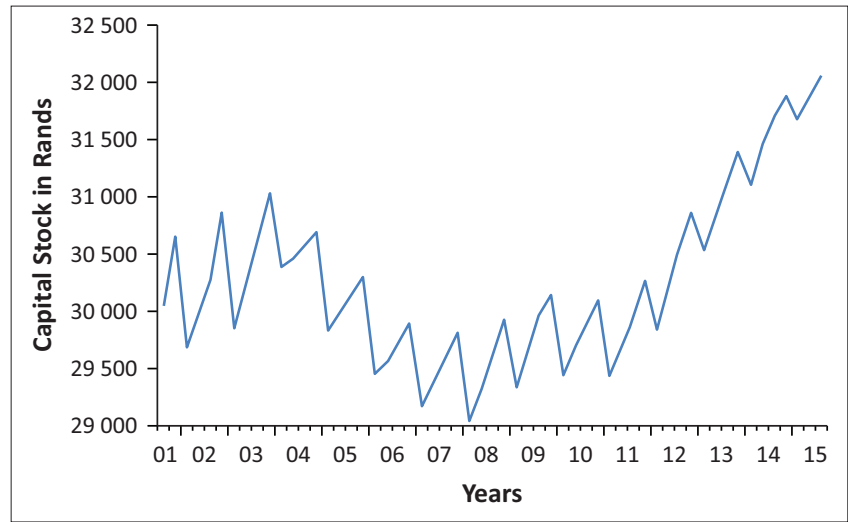

FIGURE 7: Seasonal adjusted fixed provincial government capital stock per skill adjusted labour supply (R' 2010 prices).

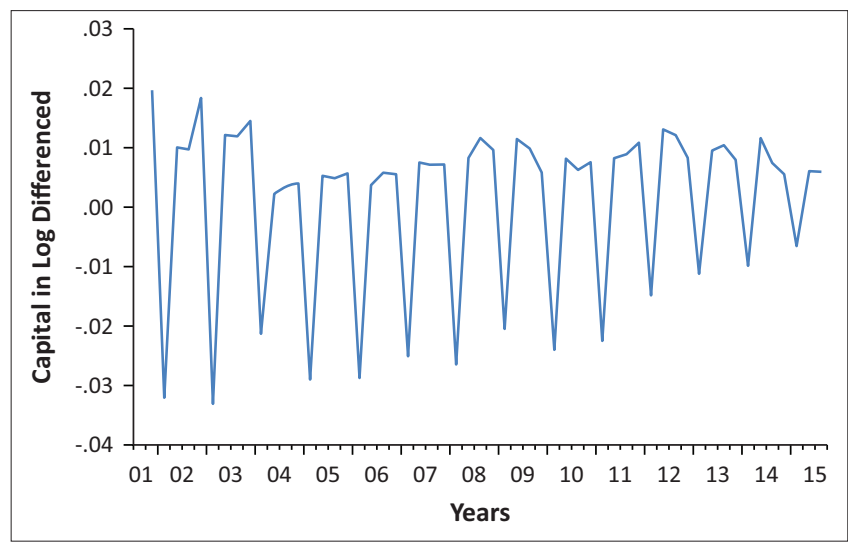

FIGURE 8: Log of first difference of the seasonal adjusted fixed provincial government capital stock per provincial skill adjusted labour supply.

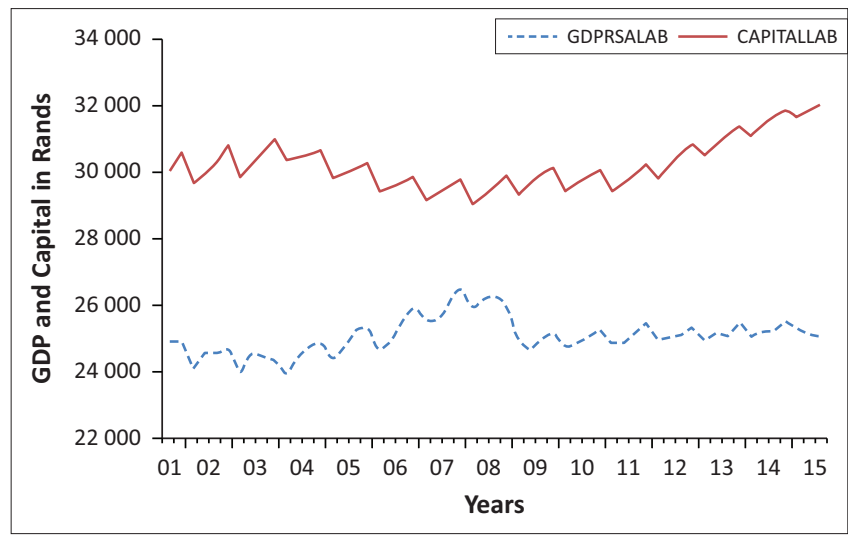

FIGURE 9: Co-movement of seasonal adjusted provincial gross domestic product per skill adjusted labour supply and seasonal adjusted fixed provincial government capital stock per skill adjusted labour supply (Rand).

$d l y_{t}=\alpha+d l \beta g_{t}+\varepsilon_{t}$

[Eqn 7]

where:

$y_{t}=$ provincial gross domestic product per skill adjusted labour supply in first difference log format, that is, $d l\left(\frac{y t}{s t}\right)$

$g_{t}=$ seasonal adjusted fixed provincial government capital stock per skill adjusted labour supply in first difference log format, that is, $d l\left(\frac{g t}{s t}\right)$

$\varepsilon_{t}=$ error term 
The coefficients ( $\alpha$ and $\beta$ ) were estimated using ordinary least squares (OLS) and regressions; using time series data from 2001 (third quarter) to 2015 (first quarter). Table 1 shows the empirical results of the regression. The $t$-statistics and adjusted $R^{2}(0.57)$ indicates that the $\alpha(-0.001)$ and $\beta(0.84)$ coefficients and the regression functions are statistically significant.

To test the hypothesis that the coefficient of the seasonal adjusted fixed provincial government capital stock per skill adjusted labour supply is equal to 0.79 , a Wald test was performed. The results suggest that the null hypothesis $(\beta=0)$ can be rejected.

Forecasting the seasonal adjusted provincial gross domestic product per skill adjusted labour supply using the above equation suggests that an average annual $6 \%$ increase in the seasonal adjusted real fixed provincial government capital stock per skill adjusted labour supply will cause an average annual $4.7 \%$ increase in the seasonal adjusted real provincial gross domestic product per skill adjusted labour supply, ceteris paribus.

The single-equation regression model that was used in this study (similar to Aschauer 1989) may sometimes entail problems of endogeneity, misspecification of the production function and causality with regard to the relation between infrastructure and productivity.

To determine the effect of unexpected shocks in public capital expenditure, VARs model was estimated. This model can indicate the dynamic effects, such as the effect on regional production, with very little restrictions. VAR can also address the problems of endogeneity and causality mentioned above.

Aschauer (1997) employs a Cobb-Douglas type of production function, expressed in terms per labourer, as:

$y=k^{\alpha \mathrm{k}} k^{\mathrm{akg}} \alpha_{k}+\alpha_{k g}=1$

[Eqn 8]

where: $y$ is output,

$k$ is a broad measure of private capital (inclusive of tangible and human capital)

$k_{g}$ is public infrastructure capital.

Constant returns to scale of private and public capital exist, while raw labour and capital yields increasing returns. Depreciation, population growth and technological developments are, however, not considered in this model.

This study estimated a VAR model similar to Aschauer's Cobb-Douglas production function. The time path of $\left(\mathrm{y}_{t}\right)$

TABLE 1: Output of the regression equation.

\begin{tabular}{lcc}
\hline Variables and test statistics & Coefficient & $\boldsymbol{t}$-Statistic \\
\hline DLOG(CAPEXRSALAB) & 0.84 & 8.60 \\
Constant & -0.001 & 0.63 \\
Adjusted $R_{2}$ & 0.57 & - \\
Durbin-Watson & 1.37 & - \\
\hline
\end{tabular}

may be influenced through the $\left(\mathrm{k}_{t}, \mathrm{~s}_{t}\right.$ and $\left.\mathrm{g}_{t}\right)$ sequence, while it can also be the other way round. The estimated VAR (in I(1) format) system is as follows:

$$
\begin{aligned}
& y_{t}=a_{10}+a_{11} y_{t-1}+a_{12} k_{t-1}+a_{13} g_{t-1}+e_{1 t} \\
& k_{t}=a_{20}+a_{21} y_{t-1}+a_{22} k_{t-1}+a_{23} g_{t-1}+e_{2 t}
\end{aligned}
$$

where:

$y_{t}=$ provincial seasonal adjusted gross domestic product per skill adjusted labour supply in first difference format, that is, $d\left(\frac{y t}{s t}\right)$ $k_{t}=$ seasonal adjusted fixed provincial government capital stock per skill adjusted labour supply in first difference format, that is, $d\left(\frac{g t}{s t}\right)$

$g_{t}=$ total national capital stock (general government and private) per national skill adjusted labour supply in the province in first difference format, that is, $d\left(\frac{k t}{s t}\right)$

It is assumed that $y_{t,}$ and $k_{t}$ are stationary; $e_{1 t,}$ and $e_{2 t}$ are white noise disturbances with standard deviations of $\sigma_{y}$ and $\sigma_{k^{\prime}}$ respectively; $g$ is assumed to be an exogenous variable, and the error terms are uncorrelated. As the lag length equals one, a first-order VAR was estimated. Additional lags could, however, be included if deemed necessary. As $y_{t}$ and $k_{t}$ may affect each other, there is also some feedback build into the system.

The model was estimated using EViews and employed quarterly data, ranging from (third quarter) 2001 to (third quarter) 2015. Four lags are included in the model. No exogenous variables, except the constant (and $g_{t}$ ), have been included. Several tests were performed on the model suggesting that (1) the estimated VAR is stationary (stable) in that modulus of all roots is less than unity and is inside the unit circle, (2) the Granger causality test $(p=0.07)$ suggests stationarity of the model and no spurious Granger causality problems exist, (3) the lag length criteria supported the use of four lags, (4) the residual Portmanteau test for autocorrelations suggested no residual autocorrelations ( $p$ at lag $5=0.001$ ), (5) at the lag order of 6 there exists no serial correlation according to the residual serial correlation Lagrange multiplier (LM) test and (6) the White heteroscedasticity test indicates the joint significance of the repressors $(p=0.25)$. The results of the diagnostic statistics in general support the appropriateness of the estimated VAR model.

Forecasting the provincial gross domestic product per skill adjusted labour supply using the VAR suggests that an average annual increase of $6 \%$ in the real provincial total fixed capital stock per skill adjusted labour supply will cause an average annual increase of $0.6 \%$ in the real provincial gross domestic product per skill adjusted labour supply, ceteris paribus.

Most studies employ co-integration and an error correction process to assess where public capital relates to economic 
progress, both short and long-term. This approach enables to determine the effects of capital stock innovations, as well as departures from a steady state, at the same time. This study tested this relationship using the Engle-Granger cointegration and error correction procedure. The assumed cointegrated relationship can be expressed as:

$\ln y_{t}=\alpha_{1}+\beta \ln k_{t}+\lambda \ln g_{t}+e_{1 t}$

[Eqn 9]

where:

$y_{t}=\log$ of provincial gross domestic product per skill adjusted labour supply, that is, $\log \left(\frac{y_{t}}{s_{t}}\right)$

$k_{t}=\log$ seasonal adjusted fixed provincial government capital stock per provincial skill adjusted labour supply, that is, $\log \left(\frac{g_{t}}{s_{t}}\right)$ $g_{t}=\log$ total national capital stock (general government and private) per national skill adjusted labour supply in the province in first difference format, that is, $\log \left(\frac{k_{t}}{s_{t}}\right)$

$\varepsilon_{t}=$ error term

To test whether the assumed co-integrated relationship indeed exists, it is important to integrate all the variables to the same order and ensure that error terms are stationary. Consider that the two variables $Y_{t}$ and $X_{t}$ are both $I(d)$, which implies long-term compatibility. Although any linear combination of $Y_{t}$ and $X_{t}$ will also be $I(d)$, if there exists a vector $(1,-\beta)^{\prime}$, such that the linear relation $\varepsilon_{\mathrm{t}}=Y_{t}-\alpha-\beta \mathrm{X}_{\mathrm{t}}$ is $I(d-b)$, and $d \geq b>0$, then following Engle and Granger (1987) $Y_{t}$ and $X_{t}$ are co-integrated in the order $(d, b)$. The augmented Dickey-Fuller test (ADF) statistics shows the variables to be indeed I(1) and therefore they are indeed integrated to the same order.

The results of the regression suggest that the $\beta$ and $\lambda$ consumption is statistically significant $(t>2)$. The adjusted $\mathrm{R}$ statistic is fairly high (0.23), but the Durban Watson statistic (of 0.83 ) is a cause of concern. However, the biggest surprise is the negative sign of the $\lambda$ coefficient. The co-integrating equation can be expressed as:

LOG $($ GDPRSALAB $)=-0.36 *$ LOG $($ CAPEXRSALAB $)+0.21 *$ LOG $($ CAPITALLABSA $)+11.61$

$$
(\mathrm{t}=-2.95) \quad(\mathrm{t}=4.30)
$$

[Eqn 10]

The results of the ADF test (using the Engle Granger critical value at $10 \%=3.04$ ) suggest that the residuals are indeed stationary and there exists a co-integration relationship between these variables at a $1 \%$ level of significance $(p=0.023)$.

After the long-term relationship between the variables is established, it was possible to construct a VECM that can simulate the short-term association between the variables. An error correction model was specified as:

$\Delta \ln y_{t}=\alpha_{2}+\beta_{2} \Delta \ln k_{t}+\lambda_{2} \Delta \ln g_{t}+\varepsilon e_{t-1}+v$ where:

$\Delta y_{t}=\log$ of provincial gross domestic product per provincial skill adjusted labour supply, that is, $\operatorname{dlog}\left(\frac{y_{t}}{s_{t}}\right)$

$\Delta g_{t}=\log$ total national capital stock (general government and private) per national skill adjusted labour supply in the province in first difference format, that is, $\operatorname{dlog}\left(\frac{k_{t}}{s_{t}}\right)$

$\Delta k_{t}=\log$ provincial total fixed capital stock per provincial skill adjusted labour supply in first difference format, that is, $\operatorname{dlog}\left(\frac{g_{t}}{s_{t}}\right)$

$\beta$ and $\lambda=$ co-integrating coefficient

$\varepsilon=$ coefficient on the lagged gap or known as equilibrium error term of one period lag

$v_{t}=$ white noise innovation

In this form, $\beta_{2}$ and $\lambda_{2}$ are called the long-term parameters and $\xi$ is termed as the short-term parameter. The residuals that have been calculated using the co-integration equation, and that have been tested for stationarity, are incorporated in an error correction equation to derive the error correction model. This proposed model seems statistically significant intuitively because the lagged residual coefficient is significant negative $(\varepsilon=-0.18$ with a $t=-2.54)$.

A possible alternative approach may be to develop a VECM similar to a Cobb-Douglas type of production function, using the Johansen co-integration test. The four variables are then integrated to the same order of 1 :

$\ln Y_{t}=a_{0}+\alpha \ln S_{t}+\beta \ln K_{t}+\gamma \ln G_{t}+\varepsilon_{t}$

[Eqn 12]

where $Y_{t}$ is the real total provincial production and income (gross domestic product) at period $t, G_{t}$ is the total national stock of capital (general government and private) in the province (excluding aggregate provincial public capital stock), $K_{t}$ is the total provincial public capital stock and $S_{t}$ is the skill adjusted total provincial labour force. $\varepsilon_{t}$ is the stationary error term. Log transformed variables were used in the model. The results of the test procedures suggest that at the 0.05 level there are indeed four co-integrating equations.

The long-term co-integration $(\mathrm{lag}=2)$ is displayed in Table 2 . There does seem to be a statistically significant long-term relationship between provincial economic growth and provincial capital (MaxEigen statistic at none $p=0.00$ ). However, it is an inverse relationship, as suggested by the negative sign.

Co-integrating equation is as follows:

$\mathrm{D}(\mathrm{LOG}(\mathrm{GDPR}))=\mathrm{C}(1) *(\mathrm{LOG}(\mathrm{GDPR}(-1))-3.74391650668 * \mathrm{LOG}$ $(\operatorname{POPSK}(-1))-0.325316360122 * \operatorname{LOG}(\operatorname{KZNCAPEXR}(-1))+$ $2.08402697198 * \operatorname{LOG}(\operatorname{SACAPEXR}(-1))+1.43959779649+\mathrm{C}(2) * \mathrm{D}$ $(\operatorname{LOG}(\operatorname{GDPR}(-1)))+\mathrm{C}(3) * \mathrm{D}(\operatorname{LOG}(\operatorname{GDPR}(-2)))+\mathrm{C}(4) * \mathrm{D}(\mathrm{LOG}$ $(\operatorname{POPSK}(-1)))+\mathrm{C}(5) * \mathrm{D}(\operatorname{LOG}(\operatorname{POPSK}(-2)))+\mathrm{C}(6) * \mathrm{D}(\mathrm{LOG}$ $(\operatorname{KZNCAPEXR}(-1)))+\mathrm{C}(7) * \mathrm{D}(\operatorname{LOG}(\operatorname{KZNCAPEXR}(-2)))+\mathrm{C}(8) * \mathrm{D}$ $(\operatorname{LOG}(\operatorname{SACAPEXR}(-1)))+\mathrm{C}(9) * \mathrm{D}(\operatorname{LOG}(\operatorname{SACAPEXR}(-2)))+\mathrm{C}(10)$ 
TABLE 2: Normalised co-integrating coefficients (standard error in parentheses).

\begin{tabular}{lccc}
\hline LOG(GDPR) & LOG(POPSK) & LOG(KZNCAPEXR) & LOG(SACAPEXR) \\
\hline 1.000000 & -3.743917 & -0.325316 & 2.084027 \\
- & $(0.86796)$ & $(0.06700)$ & $(0.82550)$
\end{tabular}

The results of the vector error correction estimates (two lags included) yield a coefficient of -0.014 and -0.013 for the first difference of the log provincial total fixed capital stock $\left(Y_{t-1}\right)$ and first difference of the log provincial total fixed capital stock two lags $\left(Y_{t-2}\right)$, respectively. Estimating the system using OLS indicates that the $\gamma_{t-1}$ and $Y_{t-2}$ coefficients are statistically significant. Testing for the joint significance (using the Wald test statistics) of $\gamma_{t-1}$ and $\gamma_{t-2}$ coefficients indicates that they are jointly significant $(p=0.014)$. This indicates that there seems to be short-term causality between the provincial capital stock and the provincial gross domestic product.

Testing the above model for statistical errors indicates that the $R^{2}$ is fairly high at 0.83 , the $\mathrm{f}$ statistic (joint significance) is statistically significant at 30 , the Breusch-Godfrey serial correlation LM test shows no serial correlation with $p=0.35$, the heteroscedasticity test: Breusch-Pagan-Godfrey indicates that the model does not have heteroscedasticity $(p=0.08)$ and the residuals are normally distributed $(p=0.67)$.

Forecasting the real aggregate level of provincial output using the VECM suggests that an average annual increase of $6 \%$ in the real provincial total fixed capital stock, ceteris paribus, will cause an average annual increase of $2.78 \%$ in the real provincial gross domestic product.

\section{Summary and conclusions}

This article assessed the extent to which provincial expenditure on fixed capital stock (infrastructure) may promote provincial economic growth using time series data of KwaZulu-Natal province, South Africa. The article introduced provincial infrastructure into a neo-classical production function model, and investigated the empirical results.

This article first reported on the construction of a new dataset for total provincial public capital stock since national accounts do not report a data time series for it. A provincial capital stock data series was designed using the perpetual inventory method (PIM).

This study found that long-term causality or effect fades over slowly. However, the nature and statistical significance of the long-term equilibrium relationship is ambiguous at best. To the contrary, some short-term equilibrium relationship was observed. Therefore, there seems to be some causality between provincial capital stock and provincial gross domestic product in the short run. This is not unsurprising given that provincial public investment projects take some years to complete.

Research by various authors studied the role of infrastructure in the economy. A number of economists argue that increased investment in public infrastructure improves growth and prosperity. David Aschauer seemingly triggered a long overdue dialogue among economists and political leaders on public capital investment in the United States. He stated that public investments enhance the quality of people's lives, raise economic progress as well as the return on private sector investments.

The major contribution of this article is that it studied the relationship between provincial public stock and provincial economic growth. It presents models that analyse the link between provincial public stock and provincial growth within a spatial economic context. Literature on spatial economic analysis within provincial context is fairly scarce in South Africa and therefore this article contributes to the spatial economic research effort. This study also developed a time series of fixed capital stock formation for the KwaZuluNatal province, which did not exist and may now also be applied by other researchers in their investigations.

Literature suggests that there is indeed some sort of optimal level public capital above which more expenditure would be wasteful and alternative expenditure would be more profitable. Unfortunately, given the reliability and inconstancy issues encountered with the models, it was not possible to venture into this particular topic. However, this topic should be high on the agenda for future research.

The application of growth models to guide expenditure on public capital seems to be a worthwhile endeavour and should be continued in further research. This article studied the role of provincial government capital accumulation and its advantages but did not model municipal infrastructure accumulation nor differentiate between private and national government capital accumulation. It would be important in future to estimate private, national, provincial and municipal capital accumulation within the context of a well-specified model.

\section{Acknowledgements Competing interests}

The authors declare that they have no financial or personal relationship(s) that may have inappropriately influenced them in writing this article.

\section{Authors' contributions}

Both the authors contributed equally to the manuscript.

\section{References}

Aschauer, D.A., 1989, How big should the public capital stock be? The relationship between public capital and economic growth, Public Policy Brief 43, Jerome Levy Economics Institute of Bard College, New York.

Aschauer, D.A., 1997, Output and employment effects of public capital, Jerome Levy Economics Institute of Bard College, New York.

Aschauer, D.A., 2000, 'Do states optimize? Public capital and economic growth', The Annals of Regional Science 34(3), 343-363. https://doi.org/10.1007/s001689 900016

Barro, R., 1990, 'Government spending in a simple model of endogenous growth', Journal of Political Economy 98(1), 103-117. https://doi.org/10.1086/261726 
Berlemann, M. \& Wesselhöft, J.E., 2012, Estimating aggregate capital stocks using the perpetual inventory method - New empirical evidence for 103 countries, Working perpetual inventory method - New empirical evidence for 103

Bogetic, Z. \& Fedderke, J.W., 2006, International benchmarking of South Africa's infrastructure performance, World Bank Policy Research Working Paper no. 3830 World Bank, Washington, DC.

Bom, P. \& Ligthart, J.E., 2010, What have we learned from three decades of research on the productivity of public capital? CESifo Working Paper Series No. 2206, Centre Discussion Paper no. 2008-2010, Center for Economic Studies, Munich.

Canning, D. \& Pedroni, P., 2004, 'The effect of infrastructure on long run economic growth', paper presented at the 1999 Econometric Society Summer Meeting, Madison, WI, 23rd-27th June.

Cheung, Y.W. \& Lai, K.S., 2000, 'On the purchasing power parity puzzle', Journal of International Economics 52(2), 321-330. https://doi.org/10.1016/S0022 1996(99)00056-2

Chow, G.C. \& Lin, A., 1971, 'Best linear unbiased interpolation, distribution, and extrapolation of time series by related series', The Review of Economics and Statistics 53(4), 372-375. https://doi.org/10.2307/1928739

Coetzee, C.E., 2017, KZN Database. KwaZulu-Natal Provincial Treasury, Pietermaritzburg, South Africa.

De Haan, J., Romp, W. \& Sturm, J.E., 2007, 'Public capital and economic growth: Key issues for Europe', in IMF International Seminar on Strengthening Public Investment and Managing Fiscal Risks from Public-Private Partnerships, Budapest, Hungary, 7-8th March.

Derbyshire, J., Gardiner, B. \& Waights, S., 2013, 'Estimating the capital stock for the NUTS2 regions of the EU27', Applied Economics 45(9), 1133-1149. https://doi.org/ 10.1080/00036846.2011.613797

Devarajan, S., Swaroop, V. \& Zou, H.F., 1996, 'The composition of public expenditure and economic growth', Journal of Monetary Economics 37(2), 313-344. https:// doi.org/10.1016/S0304-3932(96)90039-2

Egger, H. \& Falkinger, J., 2003, 'The role of public infrastructure for firm location and international outsourcing', presented at CESIFO Area Conference on Public Secto Economics, CESIFO Working Paper No. 970, Zurich, Switzerland.

Everaert, G. \& Heylen, F., 2004, 'Public capital and long-term labour marke performance in Belgium', Journal of Policy Modelling 26, 95-112. https://doi. org/10.1016/j.jpolmod.2003.11.002

Eurostat, 2017, Gross fixed capital formation (investments), viewed 08 April 2017 http://ec.europa.eu/eurostat/web/products-datasets/-/tec00011

Fedderke, J. \& Garlick, R. 2008, Infrastructure development and economic growth in South Africa: A review of the accumulated evidence, Policy Working Paper 12 , School of Economics, University of Cape Town, Cape Town.

Fedderke, J.W., Perkins, P. \& Luiz, J.M., 2006, 'Infrastructural investment in longrun economic growth: South Africa 1875-2001', World Development 34(6), 1037-1059. https://doi.org/10.1016/j.worlddev.2005.11.004

Fuente, A.D. \& Domenech, R., 2000, Human capital in growth regressions: How much difference does data quality make? Economics Department Working Paper 262, OECD, Paris.

Ghali, K.H., 1998, 'Public investment and private capital formation in a vector errorcorrection model of growth', Applied Economics 30(6), 837-844. https://doi. org/10.1080/000368498325543

Gregoriou, A. \& Ghosh, S., 2009, 'On the heterogeneous impact of public capital and current spending on growth across nations', Economics Letters 105(1), 32-35. https://doi.org/10.1016/j.econlet.2009.05.009

Griliches, Z., 1980, R\&D and the productivity slowdown, NEBR Working Paper no. 343 National Bureau of Economic Research, Cambridge.

Gupta, S., Kangur, A., Papageorgiou, C. \& Wane, A., 2011, Efficiency adjusted public capital and growth, IMF Working Paper, WP/11/217, International Monetary Fund, Washington, DC.

Haughwout, A.F., 2002, 'Public infrastructure investments, productivity and welfare in fixed geographic areas', Journal of Public Economics 83(3), 405-428. https://doi. org/10.1016/S0047-2727(00)00164-X

Holtz-Eakin, D. \& Schwartz, A.E., 1994, Infrastructure in a structural model of economic growth, NBER Working Paper Series, Working Paper No. 4824, National Bureau of Economic Research, Cambridge.
Kalaitzidakis, P. \& Tzouvelekas, V., 2007, 'Military spending and the growth-maximizing allocation of public capital: A cross-country empirical analysis', Economic Inquiry 49(4), 1029-1041. https://doi.org/10.1111/j.1465-7295.2009.00242.x

Kamps, C., 2006, 'New estimates of government net capital stocks for 22 OECD countries, 1960-2001', IMF Staff Papers 53, 120-150.

King, R.G. \& Levine, R., 1994, 'Capital fundamentalism, economic development, and economic growth', in Carnegie-Rochester Conference Series on Public Policy, North-Holland, vol. 40, pp. 259-292, June.

KwaZulu-Natal Provincial Treasury, 2016, Provincial gross domestic product model, Unpublished.

Lee, K., Pesaran, M.H. \& Smith, R.P., 1997, 'Growth and convergence in a multicountry empirical stochastic Solow model', Journal of Applied Econometrics 12(4), 357-392. https://doi.org/10.1002/(SICl)1099-1255(199707)12:4<357::AIDJAE441>3.0.CO;2-T

Márquez, M.A., Ramajo, J. \& Hewings, G.J., 2010, 'Measuring the spillover effects of public capital: A bi-regional structural vector autoregressive analysis', Letters in Spatial and Resource Sciences 3(3), 111-125. https://doi.org/10.1007/s12076010-0042-8

Munnell, A.H., 1990, 'Why has productivity growth declined? Productivity and public investment', New England Economic Review, January/February, 2-22.

Nannan, Y. \& Jianing, M., 2012, Public infrastructure investment, economic growth and policy choice: Evidence from China, School of Management, Harbin Institute of Technology, Harbin, China.

Nehru, V. \& Dhareshwar, A., 1993, 'A new database on physical capital stock: Sources, methodology and results', Revista de Análisis Económico 8(1), 37-59.

Onakoya, A.B. \& Somoye, R.O.C., 2013, 'The impact of public capital expenditure and economic growth in Nigeria', Global Journal of Economics and Finance 2(1), 1-11.

Organisation for Economic Cooperation and Development (OECD), 2001, Gross fixed capital formation, viewed 08 April 2017, from https://stats.oecd.org/glossary/ detail.asp?ID=1171

Organisation for Economic Cooperation and Development (OECD), 2009, Measuring capital - OECD manual 2009, 2nd edn., viewed 08 April 2017, from http://www. oecd-ilibrary.org/economics/measuring-capital-oecd-manual2009_9789264068476-en;jsessionid=2uhqske0ondst.x-oecd-live-03

Polasek, W., 2009, Bayesian and classical methods for completing disaggregated data: The spatial Chow-Lin approach, viewed 08 April 2017 from http://www.oecdilibrary.org/economics/measuring-capital-oecd-manual-2009_9789264068476ilibrary.org/economics/measuring-capital-o

Sava, A.S. \& Zugravu, B.G., 2010, 'Analysis of the correlations between public capital investments and economic development in Romania', Studies and Scientific Researches. Economics Edition 15, 149-155.

Statistics South Africa, 2016, Gross domestic product, Statistical Release P0441 viewed 08 April 2017, from http://www.statssa.gov.za/publications/P0441/ P04414thQuarter2016.pdf

Turnovsky, S.J., 1997, 'Fiscal policy in a growing economy with public capital' Macroeconomic Dynamics 1(03), 615-639. https://doi.org/10.1017/S136510059 7004045

Vidoli, F. \& Mazziotta, C., 2010, Spatial composite and disaggregate indicators: ChowLin methods and applications, viewed 08 April 2017, from http://new.sis-statistica. org/wp-content/uploads/2013/09/RS10-Spatial-Composite-and-DisaggregateIndicators-Chow-Lin-Methods-and-Applications.pdf

Visser, M., Pisa, N.M., Kleynhans, E.P.J. \& Wait, R., 2015, 'Identifying the comparative advantage of products and industries of South Africa's Mpumalanga province', Southern African Business Review 19(2), 27-50.

Volkwyn, B.J. \& Kleynhans, E.P.J., 2014, 'Die verskaffing van elektrisiteit deur Eskom: Die impak van beurtkrag en hoër pryse op die Suid-Afrikaanse ekonomie', Suid-Afrikaanse Tydskrif vir Natuurwetenskap en Tegnologie 33(1) viewed 08 April 2017, from http://www.satnt.ac.za/index.php/satnt/article/ viewFile/430/2597

World Bank, 1994, World development report 1994: Infrastructure for development, Oxford University Press, New York, viewed 08 April 2017, from https:// openknowledge.worldbank.org/handle/10986/5977

Zainah, P., 2009, The role of public investment in promoting economic growth: A case study of Mauritius, Service Sector Development and Impact on Poverty, Thematic Working Paper, TIPS Project, Trade \& Industrial Policy Strategies, Pretoria. 